\title{
Bronchial responsiveness to methacholine in chronic bronchitis: relationship to airflow obstruction and cold air responsiveness
}

\author{
E HELEN RAMSDALE, MARILYN M MORRIS, ROBIN S ROBERTS, FREDERICK E \\ HARGREAVE \\ From the Firestone Regional Chest and Allergy Unit, Department of Medicine, St Joseph's Hospital, and \\ Departments of Medicine and of Epidemiology and Biostatistics, McMaster University, Hamilton, Ontario, \\ Canada
}

ABSTRACT The response to inhaled methacholine is increased in patients with chronic airflow obstruction, but it is not known whether this is due to true hyperresponsiveness or is a result of the airflow obstruction. In asthmatics the response to methacholine correlates with the bronchoconstriction produced by hyperventilation of cold dry air. We studied 27 patients with a history of smoking and chronic bronchitis with a range of severity of airflow obstruction. Bronchial responses to methacholine (expressed as the provocation concentration causing a fall in $\mathrm{FEV}_{1}$ of $\left.20 \%-\mathrm{PC}_{20}\right)$ and isocapnic hyperventilation of cold dry air were measured. In 19 patients the $\mathrm{PC}_{20}$ was less than $8 \mathrm{mg} / \mathrm{ml}$ (that is, in the asthmatic range) but only three developed bronchoconstriction in response to hyperventilation. There was a linear correlation between the $\log \mathrm{PC}_{20}$ and the $\mathrm{FEV}_{1}(\mathrm{r}=0.86, \mathrm{p}<0.001)$. The results suggest that in patients with chronic airflow obstruction the response to methacholine is determined by the degree of airflow obstruction, and cannot be used in the diagnosis of asthma in the absence of additional information.

The response to inhaled methacholine is increased in patients with chronic airflow obstruction. ${ }^{1-5}$ It is not known, however, whether this represents a true increase in bronchial responsiveness or whether it reflects an apparent increase secondary to the airflow obstruction. ${ }^{67}$ Appropriate interpretation of responses to methacholine inhalation tests in the presence of airflow obstruction is necessary if the test is to be used in epidemiological studies or for the diagnosis and assessment of the severity of asthma. In addition, we may improve our understanding of underlying mechanisms in airflow obstruction.

In asthmatic patients methacholine bronchial responsiveness correlates with responsiveness to isocapnic hyperventilation of cold air. ${ }^{89}$ The increased responsiveness of the airway can therefore be demonstrated by tests which depend on two different mechanisms. The demonstration of a correlation between responsiveness to methacholine and

Address for reprint requests: Dr FE Hargreave, Firestone Regional Chest and Allergy Unit, 50 Charlton Avenue East, Hamilton, Ontario, Canada L8N 1 Y4.

Accepted 25 June 1984 cold air in patients with chronic airflow obstruction would support the presence of bronchial hyperresponsiveness. Alternatively, a correlation between the response to methacholine and the degree of airflow obstruction, together with a lack of correlation with the response to hyperventilation of cold air, would confirm the importance of obstruction, and suggest that there may not be true bronchial hyperresponsiveness. We therefore compared the response to methacholine with the response to isocapnic hyperventilation of cold air in patients with chronic bronchitis having a range of severity of airflow obstruction.

\section{Methods}

SUBJECTS

Twenty seven patients attending the Firestone Regional Chest and Allergy Clinic were selected by their availability and willingness to enter the study (table 1). All had a history of cigarette smoking, with the development of cough and sputum in adult life. Fourteen were current smokers, with cough and sputum on most days for at least three months for two consecutive years. ${ }^{10}$ Nine were ex-smokers who 
Table 1 Characteristics of the patients

\begin{tabular}{|c|c|c|c|c|c|c|c|c|}
\hline \multirow[t]{2}{*}{ Patient No } & \multirow[t]{2}{*}{ Sex } & \multirow[t]{2}{*}{ Age (y) } & \multirow{2}{*}{$\begin{array}{l}\text { Smoking } \\
\left(\text { pack } y^{*}\right)\end{array}$} & \multirow{2}{*}{$\begin{array}{l}\text { Sputum } \\
\text { (current) }\end{array}$} & \multirow[t]{2}{*}{ Atopy $\dagger$} & \multicolumn{2}{|c|}{ Eosinophilia } & \multirow[t]{2}{*}{ Treatment $\ddagger$} \\
\hline & & & & & & Blood & Sputum & \\
\hline 1 & $\mathrm{~F}$ & 56 & $46 \mathrm{EX}$ & + & 0 & No & No & ST \\
\hline 2 & M & 79 & 100 & + & 0 & No & No & ST \\
\hline 3 & $\mathrm{~F}$ & 71 & $20 \mathrm{EX}$ & + & 0 & No & No & S prn \\
\hline 4 & $\mathrm{M}$ & 62 & $56 \mathrm{EX}$ & + & 0 & No & No & STBP \\
\hline 5 & $\mathbf{M}$ & 53 & $65 \mathrm{EX}$ & + & 0 & No & No & ST \\
\hline 6 & $\mathbf{M}$ & 67 & 68 & + & 0 & Yes & No & ST \\
\hline 7 & $\mathbf{M}$ & 62 & $42 \mathrm{EX}$ & + & 0 & No & No & $S$ \\
\hline 8 & $\mathrm{~F}$ & 65 & 45 & + & 0 & No & No & Nil \\
\hline 9 & $\mathbf{M}$ & 64 & $13 \mathrm{EX}$ & + & 0 & Yes & Yes & ST \\
\hline 10 & $\mathbf{M}$ & 58 & $41 \mathrm{EX}$ & - & 0 & No & No & $\mathrm{S}$ \\
\hline 11 & $\mathbf{F}$ & 53 & 35 & + & 0 & No & No & S prn \\
\hline 12 & $\mathbf{F}$ & 66 & $30 \mathrm{EX}$ & - & 0 & No & No & $\mathrm{S}$ \\
\hline 13 & $\mathbf{M}$ & 55 & 80 & + & 0 & No & No & $\mathbf{S}$ \\
\hline 14 & $\mathbf{M}$ & 59 & $43 \mathrm{EX}$ & + & 0 & No & No & Nil \\
\hline 15 & $\mathbf{M}$ & 59 & $52 \mathrm{EX}$ & + & 0 & No & No & $\mathrm{S}$ \\
\hline 16 & $\mathbf{M}$ & 56 & $29 \mathrm{EX}$ & - & 6 & No & No & S prn \\
\hline 17 & $\mathbf{M}$ & 55 & 26 & + & 1 & No & No & SB \\
\hline 18 & $\mathbf{F}$ & 38 & 27 & + & 0 & No & No & S \\
\hline 19 & $\mathbf{F}$ & 59 & 21 & + & 0 & No & No & S prn \\
\hline 20 & $\mathrm{~F}$ & 46 & 20 & + & 0 & No & No & Nil \\
\hline 21 & $\mathrm{~F}$ & 54 & 19 & + & 9 & No & No & Nil \\
\hline 22 & $\mathrm{~F}$ & 34 & 38 & + & 0 & No & No & Nil \\
\hline 23 & $\mathrm{~F}$ & 49 & $48 \mathrm{EX}$ & + & 0 & No & No & Nil \\
\hline 24 & $\mathrm{~F}$ & 44 & 41 & + & 3 & No & No & Nil \\
\hline 25 & $\mathbf{M}$ & 75 & $36 \mathrm{EX}$ & + & 1 & No & No & Nil \\
\hline 26 & $\mathbf{M}$ & 26 & 5 & + & 2 & No & No & Nil \\
\hline 27 & $\mathbf{M}$ & 40 & 22 & + & 2 & No & No & Nil \\
\hline
\end{tabular}

*Pack years $=$ number of packs of 20 cigarettes per day $\times$ number of years' smoking.

†Number of weal and flare responses to skin prick tests with 16 common allergen extracts.

$\ddagger S$-salbutamol; T-theophylline; prn-as required; B-beclomethasone dipropionate; $\mathrm{P}$-prednisone.

continued to produce sputum, and three ex-smokers had airflow obstruction with previous but not current cough and sputum. The sputum was not purulent during the study, and the baseline $\mathrm{FEV}_{1}$ varied by less than $10 \%$ on the three study days. All patients had an $\mathrm{FEV}_{1}$ greater than $0 \cdot 8$ litres. Subjects with a lower FEV, were excluded owing to the difficulty of interpreting $20 \%$ changes in $\mathrm{FEV}_{1}$, when this is less than $150 \mathrm{ml}$. None of the patients gave a history which suggested to the attending physician that they had asthma and the $\mathrm{FEV}_{1}$, if reduced, did not increase to predicted values after salbutamol. The patients had stable chronic airflow obstruction at the time of the study. The response to prednisone was documented at the end of the study in the patients with an $\mathrm{FEV}_{1}$ less than $60 \%$ of the predicted value as part of their normal clinic assessment, provided that there were no medical contraindications; patient 11 , with an $\mathrm{FEV}_{1}$ of $66 \%$ predicted, received prednisone at the request of her physician. All patients gave written consent, and the study was approved by the hospital research committee.

\section{STUDY DESIGN}

The patients attended the laboratory on three study days, at the same time of day, and rested for 15 minutes. They had withheld inhaled bronchodilator for eight hours, short acting theophylline for 24 hours, and long acting theophylline for 48 hours. On day 1 the patients' characteristics were documented, skin prick tests for common allergens were performed, and $F E V_{1}$ and vital capacity (VC) were measured before and after administration of salbutamol $(200 \mu \mathrm{g})$. On day 2 a methacholine inhalation test was performed and on day 3 isocapnic hyperventilation of cold air. On each of the three days blood was taken for a total eosinophil count, and any morning sputum was examined for eosinophils. The study was completed within three weeks. After the main study those patients with an FEV, less than $60 \%$ of the predicted value recieved a 10 day course of prednisone ( $40 \mathrm{mg}$ daily) if there was no medical contraindication.

\section{QUESTIONNAIRE AND TESTS}

The questionnaire from the epidemiology standardisation project of the American Thoracic Society was used. " Supplementary questions related specifically to the presence or absence of symptoms consistent with asthma were added, such as nocturnal symptoms that disturbed sleep and exacerbations caused by cold air, inhaled irritants, or exercise.

Skin tests were performed by the modified prick technique $^{12}$ with extracts of 16 common allergens. Responses were measured after 10 minutes and were regarded as positive if the weal was equal to or greater than $2 \mathrm{~mm}$. 
All $\mathrm{FEV}_{1}$ and VC measurements were made on a Collins 9 litre water spirometer. Three $\mathrm{FEV}_{1}$ and VC manoeuvres were recorded, and if the $\mathrm{FEV}_{1}$ l VC\% was greater than $75 \%$ and the $\mathrm{FEV}_{1}$ greater than $80 \%$ of the predicted values then the maximum mid expiratory flow rate (MMEF) was measured by means of a forced vital capacity manoeuvre. Salbutamol ( $200 \mu \mathrm{g}$, two puffs) was administered by the experimenter from a metered dose inhaler. The inhaler was held $3 \mathrm{~cm}$ in front of the wide open mouth, the subject exhaled to functional residual capacity, the inhaler was activated just after the onset of a 5 second inspiration to total lung capacity, and the breath was held for 10 seconds. Three repeat measurements of FEV 1 and VC were made after 20 minutes, and the MMEF was repeated if applicable. The best value in each group was used for calculations. FEV 1 and VC were expressed as \% predicted $^{13}$ and the $\mathrm{FEV}_{1} / \mathrm{VC} \%$ was calculated. The percentage changes in $\mathrm{FEV}_{1}$ and $\mathrm{VC}$ after salbutamol were calculated.

The methacholine inhalation test was performed by the method described by Juniper et al..$^{14}$ The $\mathrm{FEV}_{1}$ was measured. Aerosols were generated by a Wright nebuliser (airflow rate $7.5 \mathrm{l} / \mathrm{min}$, pressure 50 $\mathrm{lb} /$ in $^{2}(344 \mathrm{kPa})$, output $0.13 \mathrm{ml} / \mathrm{min}$ ) and inhaled by tidal breathing for 2 minutes. Normal saline, followed by doubling concentrations of methacholine $(0.03-64 \mathrm{mg} / \mathrm{ml})$ were administered at intervals of 5 minutes. The $\mathrm{FEV}_{1}$ was measured 0.5 and 1.5 minutes after each inhalation. Inhalations were discontinued when there was a fall in $\mathrm{FEV}_{1}$ of $20 \%$ or more from the lowest postsaline value or when the maximum concentration had been reached. The results were expressed as the concentration of methacholine which caused a fall in $\mathrm{FEV}_{1}$ of $20 \%$ $\left(\mathrm{PC}_{20}\right)$ and this was obtained from a plot of log concentration versus percentage fall in $\mathrm{FEV}_{1}$ by linear interpolation of the last two points. In patients with a fall in $\mathrm{FEV}_{1}$ of $15-19 \%$ with $64 \mathrm{mg} / \mathrm{ml}$ methacholine the $\mathrm{PC}_{20}$ was extrapolated. With this method symptomatic asthmatics generally have a $\mathrm{PC}_{20}$ of less than $8 \mathrm{mg} / \mathrm{ml}^{15}$

Isocapnic hyperventilation of subfreezing air was carried out by the method of O'Byrne et al, ${ }^{8}$ which was modified from that described by Strauss et al. ${ }^{16}$ Cold dry air $\left(-18^{\circ} \mathrm{C}, 0 \%\right.$ relative humidity) was generated by a heat exchanger, and was inhaled in amounts that doubled with each inhalation $(7 \cdot 5,15$, 30 , and $60 \mathrm{l} / \mathrm{min}$ and at maximum voluntary ventilation) for 3 minutes at intervals of 5 minutes. Carbon dioxide was added to the inhaled air to keep the subject eucapnic during each period of hyperventilation. The response was measured by change in $\mathrm{FEV}_{1}$ from the lowest baseline value at 0.5 and 1.5 minutes after each inhalation. If there was a fall in
$\mathrm{FEV}_{1}$ the measurement was repeated at 3 minutes, and subsequently at 2 minute intervals if necessary, until the lowest value was recorded. Once the FEV started to improve the subject received the next inhalation of cold air. Inhalations were discontinued once the $\mathrm{FEV}_{1}$ had fallen by $20 \%$ or the patient had reached his maximum voluntary ventilation. The respiratory heat loss (RHL) in kilocalories/minute $(\mathrm{kcal} / \mathrm{min}-1 \mathrm{kcal}=4 \cdot 184 \mathrm{~kJ})$ was calculated for each level of ventilation by the formula $\mathrm{RHL}=\dot{\mathrm{V} E}$ $(\mathrm{HC}[\mathrm{Ti}-\mathrm{Te}]+\mathrm{HV}[\mathrm{WCi}-\mathrm{WCe}])$, where $\dot{\mathrm{VE}}=$ minute ventilation $(1 / \mathrm{min}), \mathrm{HC}=$ heat capacity of air $(0.000304 \mathrm{kcal} / \mathrm{min}), \mathrm{Ti}=$ inspired air temperature $\left({ }^{\circ} \mathrm{C}\right), \mathrm{Te}=$ expired air temperature $\left({ }^{\circ} \mathrm{C}\right), \mathrm{HV}=$ latent heat of vaporisation of water $(0.00058 \mathrm{kcal} /$ $\mathrm{mg}), \mathrm{WCi}=$ water content of inspired air $(\mathrm{mg} / \mathrm{l})$ and WCe $=$ water content of expired air $(\mathrm{mg} / \mathrm{l})$. The inspired air was dry. Expired air was assumed to be fully saturated at the expired temperature ${ }^{17}$ and the water content was obtained from standard saturation temperature relationships. ${ }^{18}$ If bronchoconstriction occurred the response was expressed as the provocation dose of RHL to cause a fall in $\mathrm{FEV}_{1}$ of $10 \%\left(\mathrm{PD}_{10}\right)$ and was obtained from the log dose response curve by linear interpolation of the last two points (see under "Analysis" for the method of determining whether sufficient RHL had been achieved).

Blood smears were stained with Wright's stain, 400 white cells were counted, and the number of eosinophils was expressed as $\mathrm{mm}^{-3}$. Sputum smears were similarly stained, and the percentage of eosinophils in relation to the total number of white cells was recorded. The upper limit of normal for blood eosinophils was $400 \mathrm{~mm}^{-3}$ and $10 \%$ for sputum.

\section{ANALYSIS}

Natural logarithms of $\mathrm{PC}_{20}$ were used for all calculations. Linear regression analysis was performed by the method of least squares to investigate the relationship between $\mathrm{PC}_{20}$ and baseline spirometric values. Patients who had no features to suggest the presence of additional asthma were treated as a separate group for further analysis. Coincidence of the regression lines was tested by examining the differences in slopes and intercepts, an unpaired $t$ test being used. ${ }^{19}$

The maximum RHL which can be generated by a patient is determined by the maximum voluntary ventilation, which in turn depends on the $F E V_{1}$. There was therefore a possibility that our patients with a reduced FEV, could not achieve the amount of RHL which would produce a bronchoconstrictor response in asthmatics with a similar $\mathrm{PC}_{20}$. The relationship between bronchial responsiveness to 
Table 2 Spirometric values and bronchial responsiveness to methacholine and respiratory heat loss (RHL)

\begin{tabular}{|c|c|c|c|c|c|c|c|c|c|c|c|c|c|}
\hline \multicolumn{3}{|c|}{ Subject FEV ${ }_{1}$} & \multicolumn{2}{|l|}{$V C$} & \multicolumn{2}{|c|}{$M M E F^{*}$} & $s$ & \multicolumn{2}{|c|}{ Steroid response $\dagger$} & \multirow{2}{*}{$\begin{array}{l}P C_{2 g} \\
(m g l m l)\end{array}$} & \multirow{2}{*}{$\begin{array}{l}\text { pred } P D_{11} \ddagger \\
(\text { (kcall/min })\end{array}$} & \multirow{2}{*}{$\begin{array}{l}\text { Max RHL\& } \\
(\text { (kcal/min) }\end{array}$} & \multirow{2}{*}{$\begin{array}{l}P D_{1 a^{\prime *}}^{* *} \\
(\text { kcal/min })\end{array}$} \\
\hline & $l$ & $\%$ pred & $l$ & $\%$ pred & $l / \min$ & $\%$ pred & \multicolumn{3}{|c|}{$\triangle F E V_{1}(\%) \triangle F E V_{1}(\%) V C(\%)$} & & & & \\
\hline 1 & 0.82 & 36 & 2.02 & 65 & & & 46 & 5 & 7 & 0.056 & 0.41 & 0.92 & - \\
\hline 2 & 004 & 48 & 2.13 & 70 & & & 15 & & & 0.18 & 0.60 & 0.63 & - \\
\hline 3 & 0.99 & 47 & 1.76 & 61 & & & 40 & 11 & 19 & 0.14 & 0.55 & 0.84 & - \\
\hline 4 & $1 \cdot 15$ & 34 & 2.90 & 60 & & & 10 & . & & 0.28 & & 1.03 & - \\
\hline 5 & 1.23 & 35 & 3.57 & 73 & & & 35 & 6 & 4 & 0.22 & 0.64 & 0.90 & - \\
\hline 6 & 1.27 & 43 & 2.59 & 60 & & & 44 & -5 & -1 & 0.15 & 0.56 & 0.70 & - \\
\hline 7 & 1.43 & 48 & 2.47 & 58 & & & 11 & & & 0.87 & 1.00 & 1.08 & - \\
\hline 8 & 1.45 & 68 & 2.76 & 94 & & & 6 & & & 0.52 & 0.85 & 0.89 & - \\
\hline 9 & 1.56 & 50 & $3 \cdot 34$ & 75 & & & 21 & 3 & 9 & 0.83 & 0.99 & 0.93 & - \\
\hline 0 & 1.60 & 52 & $3 \cdot 16$ & 73 & & & 13 & 2 & 1 & 0.056 & 0.41 & $0 \cdot 80$ & 0.62 \\
\hline 1 & 1.60 & 66 & 2.04 & 64 & & & 14 & 19 & 25 & 0.38 & 0.76 & 0.90 & \\
\hline 2 & 1.76 & 87 & 3.47 & 124 & & & 13 & 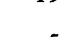 & & 0.089 & 0.47 & 1.03 & 0.60 \\
\hline 3 & 1.90 & 51 & 3.47 & 67 & & & 7 & -5 & 5 & 0.77 & 0.96 & 1.59 & - \\
\hline 4 & 2.04 & 66 & 4.47 & 104 & & & 18 & & & 0.24 & 0.66 & 1.36 & - \\
\hline 5 & $2 \cdot 18$ & 64 & 3.95 & 83 & & & 14 & & & 6.63 & 1.96 & 1.47 & - \\
\hline 6 & 2.34 & 71 & 3.76 & 82 & & & 7 & & & 0.17 & 0.59 & $1 \cdot 12$ & 0.98 \\
\hline 7 & $2 \cdot 38$ & 75 & 3.64 & 83 & & & 8 & & & $5 \cdot 1$ & 1.79 & 1.05 & - \\
\hline 8 & 2.48 & 86 & $3 \cdot 14$ & 85 & 1.40 & 41 & $\begin{array}{l}0 \\
9\end{array}$ & & & $4 \cdot 8$ & 1.76 & 2.38 & - \\
\hline 9 & 2.52 & 115 & $3 \cdot 18$ & 107 & $2 \cdot 40$ & 63 & 9 & & & $56 \cdot 3$ & 4.00 & 1.95 & - \\
\hline 0 & 2.53 & 100 & 3.42 & 104 & & & 3 & & & $33 \cdot 1$ & 3.32 & 1.05 & - \\
\hline 1 & 2.56 & 99 & 3.62 & 105 & & & 7 & & & 10 & 2.25 & 1.68 & - \\
\hline 2 & 2.56 & 84 & 3.73 & 97 & & & 4 & & & $7 \cdot 0$ & 1.99 & 1.29 & - \\
\hline 3 & 2.59 & 99 & 3.47 & 101 & $1 \cdot 86$ & 59 & 4 & & & $12 \cdot 1$ & $2 \cdot 38$ & 1.68 & - \\
\hline 4 & 3.00 & 102 & 3.58 & 94 & 3.09 & 95 & 1 & & & $51 \cdot 1$ & 3.83 & 2.00 & - \\
\hline 5 & 3.01 & 122 & 3.66 & 98 & 2.69 & 99 & 1 & & & $>64.0$ & $>4 \cdot 12$ & $2 \cdot 12$ & - \\
\hline 6 & $\begin{array}{r}3.42 \\
3.81\end{array}$ & 80 & 4.58 & 86 & 2.93 & 51 & 8 & & & $17 \cdot 2$ & 2.68 & 1.86 & - \\
\hline & 3.81 & 94 & 4.66 & 87 & NA & NA & 4 & & & $170 \cdot 0$ & $5 \cdot 69$ & 2.75 & - \\
\hline
\end{tabular}

Blank spaces signify MMEF and steroid response not measured (see under "Questionnaire and tests").

Prednisone $40 \mathrm{mg}$ daily for 10 days.

See under "Analysis."

Highest respiratory heat loss achieved by patient.

${ }^{*}$ Dashes indicate not measurable.

$\%$ pred-percentage of predicted value ${ }^{13}$; VC-vital capacity; MMEF-maximum mid expiratory flow rate; $\triangle F E V$-change in one second forced expiratory volume; $\mathrm{S}$-salbutamol; $\mathrm{PC}_{2}$-concentration of methacholine causing a $20 \%$ or greater fall in $\mathrm{FEV}_{1} ; \mathrm{PD}_{10}-$ dose of cold dry air causing a $10 \%$ or greater fall in $\mathrm{FEV}_{1} ; \mathrm{NA}-$ not available.

Conversion: traditional to SI units-Respiratory heat loss: $1 \mathrm{kcal}=4 \cdot 184 \mathrm{~kJ}$.

methacholine and cold air in asthmatics may be expressed by the equation $\log _{e} P_{10}=0.048+$ $0.3291 \log _{\mathrm{e}} \mathrm{PC}_{20}{ }^{8}$ We derived a predicted $\mathrm{PD}_{10}$ ( $\mathrm{kcal} / \mathrm{min}$ ) for our patients from this equation, to determine whether they had achieved sufficient RHL.

\section{Results}

In 19 patients bronchial responsiveness to methacholine was less than $8 \mathrm{mg} / \mathrm{ml}$-that is, in the asthmatic range (table 2). Eighteen of these had evidence of airflow obstruction (in 16 the FEV was less than $80 \%$ predicted, in two the $\mathrm{FEV}_{1} / \mathrm{VC} \%$ was less than $78 \%$ ), and in the remaining one there was a reduced MMEF, with only a mild increase in bronchial responsiveness.

There was a linear correlation between the log $\mathrm{PC}_{20}$ and the degree of airflow obstruction, whether this was expressed as $\mathrm{FEV}_{1}(\mathrm{l})(\mathrm{r}=0.86, \mathrm{p}<0.001)$, (fig), $\mathrm{FEV}_{1}$ (\% predicted) $(\mathrm{r}=0.79, \mathrm{p}<0.001)$, or $\mathrm{FEV}_{1} / \mathrm{VC} \%(\mathrm{r}=0.81, \mathrm{p}<0.001)$. The more severe the airflow obstruction the greater was the increase in bronchial responsiveness to methacholine (that is, the lower was the $\mathrm{PC}_{20}$ ).

The relationship between bronchial responsiveness to methacholine and cold air in asthmatic patients is such that we expected most of the patients with a $\mathrm{PC}_{20}$ of less than $8 \mathrm{mg} / \mathrm{ml}$ to develop bronchoconstriction in response to hyperventilation of cold air. Only three subjects, however, (Nos 10, 12 and 16), developed bronchoconstriction and had a measurable $P D_{10}$ which was associated with symptomatic chest tightness (table 2). In the remaining 16 patients with a $P_{20}$ in the asthmatic range there was a discrepancy between the bronchial responsiveness to methacholine and cold air. Thirteen of these patients achieved sufficient RHL to produce a bronchoconstrictor response in asthmatics with a similar $\mathrm{PC}_{20}$ (table 2). The three patients with a $\mathrm{PC}_{20}$ greater than $5 \mathrm{mg} / \mathrm{ml}$ did not achieve sufficient RHL, but this is not an unusual finding in cases of mild asthma.

The three patients who developed bronchoconstriction in response to cold air all had a greater response to methacholine than the others with a similar amount of airflow obstruction (fig). This suggests that in these patients the response to 


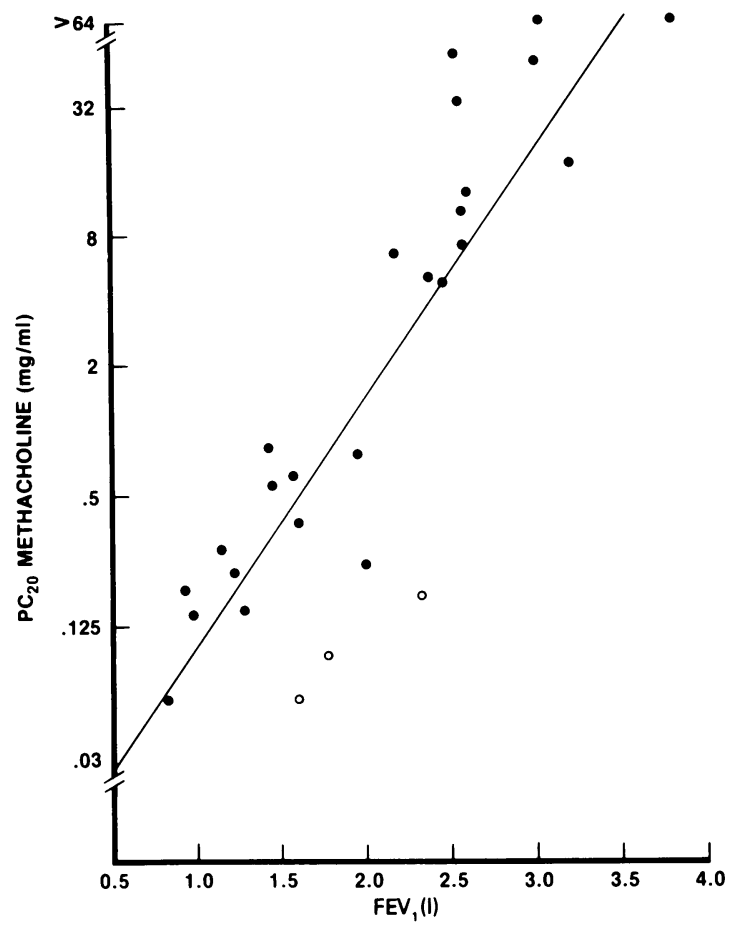

Relationship between airflow obstruction $\left(F E V_{1}, l\right)$ and bronchial responsiveness to methacholine $\left(P C_{20} \mathrm{mg} / \mathrm{ml}\right)$. $\bigcirc$ Patients responsive to cold air. The solid line represents the regression line $(r=0.86, p<0.001)$.

methacholine was determined partly by the airflow obstruction and partly by true bronchial hyperresponsiveness.

It seemed possible that 17 patients had asthma as well as chronic bronchitis since they had atopy, eosinophilia, a bronchoconstrictor response to $\mathrm{RHL}$, or an increase in $\mathrm{FEV}_{1}$ of more than $15 \%$ after treatment with salbutamol or steroid (tables 1 and 2). Data on the remaining 10 patients (Nos 2, 7, $8,13,15,18-20,22,23$ ) were therefore analysed as a separate group. There was a strong linear relationship between $\log \mathrm{PC}_{20}$ and $\mathrm{FEV}_{1}(\mathrm{l}),(\mathrm{r}=0.90, \mathrm{p}<$ $0 \cdot 001)$. There was no significant difference between this regression line (slope or intercept) and that of the group as a whole $(\mathrm{p}>0.5)$.

\section{Discussion}

This study has confirmed that the bronchial response to inhaled methacholine is increased in patients with chronic bronchitis when airflow obstruction is present. In addition, the degree of hyperresponsiveness correlated well with the degree of airflow obstruction. Unlike asthmatics, however, most patients did not develop bronchoconstriction in response to
RHL-that is, there was a discrepancy between the bronchial response to methacholine and RHL. We interpret these findings as support for the hypothesis that the increased response to methacholine in these patients is due primarily to the airflow obstruction, and that the lack of response to RHL reflects the absence of true hyperresponsiveness of the airway.

The presence of an increased response to methacholine in the absence of a bronchoconstrictor response to RHL requires an explanation, especially since in asthmatics there is a good correlation between responses to the two tests. ${ }^{89}$ We suggest, as have others, ${ }^{67}$ that the apparent hyperresponsiveness to methacholine is a reflection of the decreased airway calibre. There are several ways in which a reduction in $\mathrm{FEV}_{1}$ could cause an increased responsiveness to a contractile agent. ${ }^{6}$ A given small change in the length of a smooth muscle cell will cause a larger proportional change in the diameter of a small airway than a large one. In addition, owing to Poiseuille's Law, as the airway narrows, a small change in the radius will result in a much larger increase in resistance, and decrease the airflow proportionately more. As the $\mathrm{FEV}_{1}$ decreases, the absolute change in litres that corresponds to a $20 \%$ fall also decreases. This will magnify any measurement errors. In an attempt to minimise this latter problem, we included mainly patients with an FEV greater than 1 litre. Finally, the change in deposition of the aerosol from peripheral to central in the presence of airflow obstruction may also increase the response when $\mathrm{FEV}_{1}$ is used as the index of bronchoconstriction. ${ }^{20}$ In contrast to the response to methacholine, the decreased calibre of the airway did not alter the airway response to respiratory heat loss. This lack of response to respiratory heat loss in chronic airflow obstruction, despite responsiveness to prednisone and bronchodilators, has been reported recently. ${ }^{21}$ In this regard the patients with chronic bronchitis were responding as normal subjects, who do not develop bronchoconstriction in response to respiratory heat loss. This implies that the cold air has no inherent contractile properties, and that predisposing factors are present in asthmatic airways which promote the bronchoconstrictor response. The mechanism has not been established, but may be due to increased responsiveness of the muscle itself, easier release of mediators, or both. ${ }^{22-24}$ Interestingly, the three patients who responded to cold air had a greater response to methacholine than others with a similar degree of airflow obstruction. This suggests that in these subjects there was an increased response to methacholine resulting from obstruction and in addition true bronchial hyperresponsiveness as found in asthmatics. It may be possible to define an 
expected response to methacholine for a given degree of airflow obstruction. $\mathrm{A} \mathrm{PC}_{20}$ lower than this could then be used to support a diagnosis of asthma. More patients need to be studied, however, to confirm this possibility.

Problems of semantics are inevitable in the classification of patients with "chronic bronchitis." The recognition of asthma in patients with chronic airflow obstruction is difficult. It has been conventional to try to avoid any possibility of associated asthma by excluding patients with atopy, eosinophilia, or a greater than $15 \%$ improvement in $\mathrm{FEV}_{1}$ after treatment with bronchodilator or steroid. None of these, however are specific measurements. Atopy and eosinophilia are associated with asthma, but are not diagnostic; asthma may or may not be present. A specific percentage increase in $\mathrm{FEV}_{1}$ after treatment with bronchodilator or steroid may not be an indication of the same underlying pathological mechanism when the $\mathrm{FEV}_{1}$ is $1 \mathrm{l}$ as when it is $2.51 .^{25} \mathrm{We}$ chose, therefore, to select for the study patients with a history of cigarette smoking who had chronic cough and sputum consistent with chronic bronchitis, and to document their characteristics. None of them gave a history to suggest that the primary diagnosis was asthma. This approach was supported by the results of the study. Firstly, exclusion of the patients with the above criteria or with a bronchoconstrictor response to respiratory heat loss did not alter the conclusion that the response to methacholine is determined by the level of airflow obstruction. Secondly, the usual exclusion criteria would not have applied to patients 10 and 12 , who developed bronchoconstriction in response to respiratory heat loss. Thus further investigation is required to determine whether a bronchoconstrictor response to respiratory heat loss is a more specific test for the presence of asthma in chronic airflow obstruction. It may not be possible, however, to demonstrate a mild degree of asthma in patients with severe airflow obstruction since the amount of respiratory heat loss achieved at maximum ventilation when the $\mathrm{FEV}_{1}$ is less than a litre may be insufficient to stimulate bronchoconstriction.

Whether the response to methacholine in patients with chronic airflow obstruction is determined by the level of airway function, or whether bronchial hyperresponsiveness leads to the development of obstruction, cannot be answered without a longitudinal epidemiological study. Unfortunately a previous study, ${ }^{26}$ which showed a relationship between bronchial responsiveness and the rate of decline in $F E V_{1}$, measured the responsiveness at the end of the study period, and no conclusion can be drawn about cause and effect.
In summary, this study has showed that in chronic bronchitis the response to methacholine is related to the degree of airflow obstruction. This suggests that in the absence of additional information an increase in bronchial responsiveness to methacholine cannot be used to diagnose asthma in the presence of chronic airflow obstruction. The hypothesis that the presence of a bronchoconstrictor response to respiratory heat loss in patients with chronic airflow obstruction reflects true bronchial hyperresponsiveness requires further investigation. Further studies are needed to investigate the relationship between obstruction and true bronchial hyperresponsiveness.

We thank Glaxo Canada Ltd, Toronto, for the supply of salbutamol and the Upjohn Company of Canada Ltd, Don Mills, Ontario, for the supply of prednisone. We are grateful to Drs SO Pugsley, JLC Morse, and MT Newhouse for allowing us to study their patients, and to Dr EE Daniel for helpful discussion of the manuscript. This work was supported by a grant from the Medical Research Council of Canada. EHR is a fellow of the Ontario Ministry of Health.

\section{References}

1 Oppenheimer EA. Airways obstruction before and after isoprenaline, histamine, and prednisolone in patients with chronic obstructive bronchitis. Lancet 1968;i:522-6.

2 Fletcher CM. Bronchial infection and reactivity in chronic bronchitis, J R Coll Physn Lond 1968;2:18390.

3 Boushey HA, Holtzman MJ, Sheller JR, Nadel JA. Bronchial hyperreactivity. Am Rev Respir Dis 1980;121:389-413.

4 Ramsdell JW, Nachtwey FJ, Moser KM. Bronchial hyperreactivity in chronic obstructive bronchitis. $\mathrm{Am}$ Rev Respir Dis 1982;125:289-32.

5 Bahous J, Cartier A, Ouimet G, Pineau L, Malo J-L. Nonallergic bronchial hyperexcitability in chronic bronchitis. Am Rev Respir Dis 1984;129:216-20.

6 Benson MK. Bronchial hyperreactivity. Br J Dis Chest 1975;69:227-39.

7 Tattersfield AE. Measurement of bronchial reactivity: a question of interpretation. Thorax 1981;36:561-5.

8 O'Byrne PM, Ryan G, Morris M, McCormack D, Jones NL, Morse JLC, Hargreave FE. Asthma induced by cold air and its relation to nonspecific bronchial responsiveness to methacholine. Am Rev Respir Dis 1982;125:281-5.

9 Aquilina AT. Comparison of airway reactivity induced by histamine, methacholine, and isocapnic hyperventilation in normal and asthmatic subjects. Thorax 1983;38:766-70.

10 American Thoracic Society. Chronic bronchitis, asthma and pulmonary emphysema. A statement by the committee on diagnostic standards for nontuberculous respiratory disease. Am Rev Respir Dis 1962;82:762-8. 
11 Ferris BA. Epidemiology standardisation project. $A m$ Rev Respir Dis 1978;118 suppl:10-27.

12 Pepys J. Skin tests in diagnosis. In: Gell PGH, Coombs RRA, Lachmann PJ, eds. Clinical aspects of immunology. 3rd ed. Oxford: Blackwell Scientific Publications, 1975:55-80.

13 Morris JF, Koski A, Johnson LC. Spirometric standards for healthy nonsmoking adults. Am Rev Respir Dis 1971; 103:57-67.

14 Juniper EF, Frith PA, Dunnett C, Cockcroft DW, Hargreave FE. Reproducibility and comparison of response to inhaled histamine and. methacholine. Thorax 1978;33:705-10.

15 Hargreave FE, Ryan G, Thomson NC, et al. Bronchial responsiveness to histamine or methacholine in asthma: measurement and clinical significance. $J$ Allergy Clin Immunol 1981;68:347-55.

16 Strauss RH, McFadden ER Jr, Ingram RH Jr, Deal EC $\mathrm{Jr}$, Jaeger JJ. Influence of heat and humidity on the airway obstruction induced by exercise in asthma. $J$ Clin Invest 1978;61:133-40.

17 Ferrus L, Guenard H, Vardon G, Varene P. Respiratory water loss. Respir Physiol 1980;39:367-81.

18 West RC. Handbook of chemistry and physics. 58th ed. Cleveland, Ohio: CRC Press, 1977.
19 Kleinbaum DG, Kupper LL. Applied regression analysis and other multivariable methods. North Scituate, Massachusetts: Duxbury Press, 1978.

20 Newhouse MT, Ruffin MB. Deposition and fate of aerosolized drugs. Chest 1978;73S:936-42S

21 Arnup ME, Mendella LA, Anthonisen NR. Effects of cold air hyperpnoea in patients with chronic obstructive lung disease. Am Rev Respir Dis 1983;128:236-9.

22 Findlay SR, Lichtenstein LM. Basophil "releasability" in patients with asthma: measurement and clinical significance. J Allergy Clin Immunol 1981;68:347-55.

23 Barnes PJ, Brown MJ. Venous plasma histamine in exercise-and hyperventilation-induced asthma in man. Clin Sci 1981;61:159-62.

24 Lee TH, Nagy L, Nagakura T, Walport MJ, Kay AB. Identification and partial characterization of an exercise-induced neutrophil chemotactic factor in bronchial asthma. J Clin Invest 1982; 69:889-99.

25 Arnup ME, Mendella LA, Anthonisen NR. COPD or not COPD. Am Rev Respir Dis 1984;129:200-1.

26 Barter CE, Campbell AH. Relationship of constitutional factors and cigarette smoking to decrease in 1-second forced expiratory volume. Am Rev Respir Dis 1976;113:305-14. 